\title{
PERAN SEMANTIS DALAM KONSTRUKSI DATIF BAHASA JEPANG
}

\author{
Made Ratna Dian Aryani \\ e-mail: dian_aryani@unud.ac.id \\ Sastra Jepang Fakultas Ilmu Budaya universitas Udayana
}

\begin{abstract}
Abstrak-Penelitian ini bertujuan mendeskripsikan verba-verba yang memunculkan kontruksi datif dan peran semantis yang muncul dalam konstruksi datif dalam struktur kalimat bahasa Jepang (BJ), yang meliputi peran agentif, peran benefaktif, peran pengalam, dan peran objektif. Teori yang dipergunakan dalam penelitian ini adalah teori dari Givon (2001), Teori Tata Bahasa Kasus dari Cook (1979), dan teori kebermarkahan dari Nitta (1991). Sumber data diambil dari korpus berbahasa Jepang yaitu www.kotonoha.gr.jp/shonagon/
\end{abstract}

Penelitian ini menunjukkan bahasa Jepang (BJ) merupakan bahasa yang bertanda atau berkasus. Kasus dalam bahasa Jepang di sini, berkaitan erat dengan sistem kebermarkahan dalam struktur kalimat bahasa Jepang. Pemarkah tersebut dilekatkan setelah nomina (kata benda). Pemarkah atau partikel yang menyatakan objek langsung adalah pemarkah akusatif ' $o$ ' dan pemarkah datif ' $n i$ ' sebagai pemarkah objek tidak langsung. Verba yang ditemukan dalam penelitian ini adalah tatakareta 'telah ditepuk', yonde kureta 'telah membacakan', tooraseta 'telah (menyebabkan) melewati', dan oboeta 'telah ingat' yang dapat memunculkan objek ganda, yaitu urutan objek langsung dan objek tidak langsung. Hasil penelitian ini, (1) menunjukkan verba-verba yang memungkinkan munculnya objek ganda, khususnya objek tidak langsung (OTL) dalam konstruksi bahasa Jepang merupakan verba transitif atau verba aksi dan verba intransitif yang berupa idou doushi 'verba bergerak' saja yang berpola kausatif bahasa Jepang (BJ) \{ $\sim$ seru/ saseru $\}$ bermakna menyuruh/ menyebabkan, dan (2) peran semantis yang muncul dalam konstruksi datif dalam struktur kalimat bahasa Jepang (BJ) meliputi (a) peran agentif, (b) peran benefaktif, (c) peran pengalam, dan (c) peran objektif. Secara semantis verba-verba yang memunculkan peran semantis tersebut merupakan keizoku doushi 'verba kontinuatif' dan shunkan doushi 'verba pungtual'.

Kata kunci: datif, agentif, benefaktif, pengalam, objektif

Abstract-This study aims to describe the verbs that give rise to dative construction and the semantic roles that arise in dative construction in Japanese sentence structure, which includes the agentif role, benefactive role, experience role, and objective role. The theory used in this study is the theory of Givon (2001), Cook's Case Grammar Theory (1979), and the theory of inheritance from Nitta (1991). Data sources are taken from the Japanese corpus, www.kotonoha.gr.jp/shonagon/

This research shows Japanese language is a language marked or a file. The case in Japanese here is closely related to the system of inheritance in the Japanese sentence structure. The marker is attached after noun (noun). The markers or particles that state direct objects are accusative markers ' $\boldsymbol{o}$ ' and markers datif ' $\boldsymbol{n} \boldsymbol{i}$ ' as markers of indirect objects. The verb found in this study is tatakareta 'has been tapped', yonde kureta 'has read', tooraseta 'has (caused) passed', and oboeta 'has remembered' which can bring up multiple objects, namely the order of direct objects and indirect objects. The results of this study, (1) show the verbs that allow the emergence of multiple objects, especially indirect objects (IO) in the construction of Japanese, are transitive verbs or action verbs and intransitive verbs in the form of idou doushi 'moving verbs' are causative in Japanese language $\{\sim$ exciting / saseru $\}$ means to make / cause, and (2) the semantic roles that arise in the dative construction of Japanese sentence structures (BJ) include (a) agentive roles, (b) benefactive roles, (c) experience roles, and (c) objective roles. Semantically the verbs that give rise to the semantic role are keizoku doushi 'continuous verbs' and shunkan doushi 'pungtual verbs'.

Keywords: dative, agentive, benefactive, experience, objective. 


\section{PENDAHULUAN}

Bahasa Jepang memiliki tiga kekhasan dan keunikan yang menarik untuk diteliti. Pertama, Bahasa Jepang merupakan bahasa yang mempunyai cara-cara untuk menunjukkan tingkatan kesopanan berbahasa, yakni dengan menggunakan ungkapan atau kalimat untuk meninggikan orang lain dan merendahkan diri sendiri. Ragam bahasa sopan sebagai bahasa yang mengungkapkan rasa hormat terhadap lawan bicara atau orang ketiga (Matsuoka, 2000:54). Tingkat kesopanan Bahasa Jepang pun mempergunakan unsur-unsur gramatikal dengan menggunakan perubahan kosakata (gramaticalised politeness) serta pilihan kata (leksikal politeness).

Kekhasan dan keunikan kedua adalah adanya sistem kebermarkahan dalam bahasa Jepang (BJ). Tsujimura (1996: 165) menyatakan bahwa dalam setiap konstituen bahasa Jepang (BJ), terdapat pemarkah untuk menjelaskan fungsinya, yaitu pemarkah nominative subjek (topik) yaitu $g a$ dan topik adalah $w a$, pemarkah akusatif objek adalah o/wo, pemarkah datif adalah $n i$, pemarkah genitif kepemilikan adalah no, pemarkah pelengkap adalah to. Pemarkah atau yang biasa disebut sebagai partikel (kata bantu) merupakan salah satu jenis kata yang memiliki sifat tidak bisa berdiri sendiri, tidak mengalami perubahan bentuk, kehadirannya berposisi setelah nomina, dan berfungsi menghubungkan kata dengan kata, frasa dengan frasa, kalimat dengan kalimat. Bila suatu kata yang hanya terdiri atas partikel, akan tidak mempunyai arti apa-apa. Kaidah bahasa Jepang (BJ) menyatakan bahwa partikel sesungguhnya tidak mempunyai arti, kecuali arti yang berhubungan dengan konteksnya.

Kekhasan dan keunikan ketiga adalah secara tipologis Bahasa Jepang memiliki silabel terbuka, secara struktur (baik dari segi struktur frasa maupun struktur kalimat), Bahasa Jepang mengikuti urutan MD (MenerangkanDiterangkan), dan Bahasa Jepang pun berpola urutan SOV (Subjek - Objek - Verb). Untuk mewadahi makna struktur yang lebih tinggi, yaitu struktur frasa, diperlukan suatu kaidah struktur frasa. Secara lintas bahasa ada dua kaidah struktur frasa, yaitu struktur frasa dengan hukum 'Diterangkan Menerangkan' (DM) dan 'Menerangkan Diterangkan' (MD). Dalam Bahasa Jepang bila dua morfem tersebut diurutkan secara bergantian, menjadi tidak berterima secara gramatikal, karena dalam Bahasa Jepang diperlukan pemarkah dalam pembentukan frasa.

Dalam kaitannya dengan verba di dalam kalimat, menurut Verhaar (1999) verba dalam suatu konstruksi kalimat merupakan konstituen induk. Verba sebagai konstituen induk mempunyai tugas melahirkan konstituenkonstituen yang lain. Konstituen tersebut dalam kalimat disebut dengan nomina. Sifat-sifat (peran) nomina juga bergantung pada sifat yang dimiliki oleh verba sebagai induk. Bila kehadiran konstituen datif tersebut tidak wajib, akan diasumsikan verba tersebut bukanlah sebagai verba yang menuntut kehadiran datif. Kemunculan konstituen-konstituen lain, yaitu nomina dalam suatu struktur kalimat merupakan salah satu ciri dari nomina. Di bawah ini merupakan contoh struktur kalimat dengan kategori gramatikal yang menunjukkan datif dalam BJ:

\section{(1) 彼が 他人に Kare ga tanin ni dia(laki-laki)-Nom orang lain-Dat}

\author{
罪を かぶせた。 \\ tsumi o kabuseta. \\ kesalahan-Ak menimpakan-lamp \\ 'Dia telah menimpakan kesalahan kepada \\ orang lain.'
}

Pada contoh kalimat (1), argumen kare ga 'dia (laki-laki) adalah pelaku (agen), tanin $n i$ 'kepada orang lain' adalah tujuan/sasaran (datif/OTL), tsumi o 'kesalahan' adalah tema (objek), dan kabuseta 'telah membagikan/menyebarkan' adalah verba aksi/tindakan. Kalimat (1) tersebut argumen datif dengan pemarkah $\boldsymbol{n i}$ bermakna 
sebagai sasaran, yaitu ditujukan 'kepada' dalam bahasa Indonesia (BI).

\section{TEORI \& METODOLOGI}

Penelitian ini menggunakan metode deskriptif, yaitu bertujuan membuat deskripsi yang sistematis, faktual dan akurat mengenai data, sifat-sifat, serta fenomena-fenomena yang diteliti sebagaimana diungkapkan Djajasudarma (1993:8). Penjelasan tentang fenomena kebahasaan ini terkait dengan bahasa sebagai bahasa individu atau bahasa yang bersifat universal. Penelitian datif bahasa Jepang (BJ) ini merupakan bentuk penelitian deskriptif yang bersifat kualitatif, eksplanatoris, dan sinkronis karena pendeskripsian data dalam penelitian ini dilakukan dengan cara memberikan gambaran dan penjelasan keadaan atau realitas bahasa seperti apa adanya.

Peran Pemarkah [ni] Menurut Nitta (1991) dan Sugai (2000)

\begin{tabular}{|c|c|c|}
\hline No. & Nitta (1991) & Sugai (2000) \\
\hline 1. & $\begin{array}{l}\text { 物の授受行う相 } \\
\text { 手を表す. “Mono } \\
\text { no juju okonau aite } \\
\text { o arawasu' } \\
\text { Menyatakan pihak } \\
\text { penerima/pemberi } \\
\text { barang. } \\
\text { (kepada /untuk ) }\end{array}$ & $\begin{array}{l}\text { 伝達先 } \\
\text { "Dentatsusaki" } \\
\text { Menyatakan } \\
\text { transmisi } \\
\text { tujuan. } \\
\text { (kepada } \\
\text { ／untuk ) }\end{array}$ \\
\hline 2. & $\begin{array}{l}\text { 動詞を使役文に } \\
\text { したときの、動 } \\
\text { 詞の目的語を表 } \\
\text { す。 "Dōshi o } \\
\text { shiekibun ni shita } \\
\text { toki no, dōshi no } \\
\text { mokutekigo } \\
\text { arawasu" } \\
\text { Menyatakan objek } \\
\text { dari kalimat } \\
\text { kausatif. }\end{array}$ & $\begin{array}{l}\text { 起点 “Kiten” } \\
\text { Menyatakan } \\
\text { asal. } \\
\text { (dari ) }\end{array}$ \\
\hline 3. & $\begin{array}{l}\text { 動詞を受身文に } \\
\text { したときの動詞 } \\
\text { の主体を表す。 } \\
\text { ”Dōshio ukemibun } \\
\text { ni shita toki no }\end{array}$ & $\begin{array}{l}\text { 動 作 者 } \\
\text { "Dousasha" } \\
\text { Menyatakan } \\
\text { gerakan. } \\
\text { (oleh ) }\end{array}$ \\
\hline
\end{tabular}

\begin{tabular}{|l|l|}
\hline & $\begin{array}{l}\text { dōshi no, shutai o } \\
\text { arawasu, } \\
\text { Menyatakan subjek } \\
\text { dari kalimat pasif. }\end{array}$ \\
\hline
\end{tabular}

Penjelasan poin-poin peran pemarkah $\boldsymbol{n i}$ dari Nitta (1991) dan Sugai (2000) yang dipergunakan sebagai acuan dalam penelitian ini, yaitu yang menyatakan tujuan (pemberi/penerima), objek sasaran atau gerakan, kalimat pasif, kalimat kausatif dan asal.

Teori TBK dari Cook (1979) ini dipergunakan untuk menjelaskan struktur kalimat dalam pembentukan struktur kalimat datif BJ. Kasus proposisi ada yang bersifat wajib (wajib hadir) dan ada yang bersifat opsional/pilihan dalam struktur lahir. Kasus proposisi yang kehadirannya bersifat wajib disebut peran proposisi teraga (overt: kasus proposisi yang diimplikasikan oleh verba dan wajib hadir dalam struktur lahir), sedangkan kasus proposisi yang kehadirannya bersifat opsional/pilihan disebut peran proposisi tak teraga (covert: kasus proposisi yang diimplikasikan oleh verba tetapi opsional dalam struktur lahir dan hadir dalam struktur batin atau struktur logika). Modifikasi yang dilakukan Cook hanya menggunakan lima kasus, yaitu (1) Agent (A); (2) Experiencer (E); (3) Benefactive (B); (4) Object (O); dan (5) Locative (L) (Cook 1979: 124-125). Namun, dalam penelitian ini hanya akan dianalisis 4 kasus saja, yaitu Agent (A), Experiencer (E), Benefactive (B), dan Object $(\mathrm{O})$. Hal ini sesuai dengan topik dari penelitian ini yang melibatkan argumen datif 'yokaku' sebagai objek taklangsung dan struktur kalimat BJ lain yang berpemarkah $\boldsymbol{n i}$, namun bukan sebagai fungsi keterangan, baik itu keterangan tempat atau pun keterangan waktu.

Dalam sistem verba sebagai pusat dalam proposisi, kasus-kasus sebelumnya ditentukan oleh fitur-fitur yang terdapat di dalam verba. Pengertian kasus dalam hal ini tidak mutlak di dalam penggunaannya, tetapi dalam hubungannya dengan fitur-fitur tersebut. Kerangka kasus proposisi dalam kerangka teori ini dapat ditentukan sebagai berikut: 
Agent : kasus yang diperlukan oleh verba aksi yang menunjukkan pelaku dari aksi tersebut, dan kasus ini biasanya digunakan untuk makhluk hidup (animate) tetapi tidak selalu.

Experiencer : kasus yang diperlukan oleh verba pengalami yang menunjuk pada makhluk hidup yang mengalami gejala psikologis atau yang berkaitan dengan perasaan, emosi, kognisi.

Benefactive : kasus yang menyatakan kepemilikan, mendapat atau menyatakan kehilangan yang mengacu pada suatu objek.

Object

: hal-hal yang menyatakan:

(a) kasus yang diperlukan oleh verba yang menyatakan keadaan

(b) kasus yang diperlukan oleh verba proses yang menyebabkan objek pengalami akan mengubah keadaan;

(c) kasus yang diperlukan merupakan objek sebagai suatu pengalaman, dan merupakan stimulus yang menyebabkan suatu keadaan;

(d) objek merupakan kasus yang menyatakan kepemilikan benda atau benda yang telah ditransfer.

Locative : kasus yang diperlukan oleh verba lokatif yang menyatakan lokasi dari suatu objek atau perubahan dari lokasi suatu objek (Cook, 1979: 52).

Cook menjelaskan bahwa predikat adalah verba dalam pengertian umum dan argumen verba sangat diperlukan untuk menentukan kasus. Model ini disebut Model Matriks Tata Bahasa Kasus. Mengingat dalam penelitian ini yang menjadi pokok bahasan adalah datif [ $n i$ ], maka kerangka teori mengenai poin Locative tidak akan dibahas secara detail.

\section{TEMUAN \& PEMBAHASAN}

\section{A. Agentif}

Kasus Agentif menyatakan entitas yaitu mahluk hidup (animate) yang menjadi pelaku suatu aksi/perbuatan. Kasus agentif adalah entitas yang menyebabkan pemerolehan atau kehilangan sesuatu. Pada data kalimat (1) dan (2), verba た たかれた/tatakareta 'telah ditepuk' dan verba も らいました/moraimashita 'telah menerima' secara peran semantis merupakan Agentif yang menyatakan sumber atau asal.

Data 1 :

私は

友達に 片を

Watashi wa

$\mathbf{E}$

tomodachi ni kata o

Saya-Top teman-Dat bahu-Ak

たたかれた。

tatakareta.

ditepuk -lampau

'Bahu saya ditepuk oleh teman.'

(Korpus, Gengo: 2010)

Pada data kalimat (1) verba tatakareta 'telah ditepuk' mengikat kasus pengalam , yaitu watashi wa 'saya' yang berperan sebagai pengalam (orang yang mengalaminya), pada konstituen berpemarkah datif yaitu tomodachi $n i$ 'oleh teman' yang berperan sebagai kasus agentif (pelaku yang melakukan tindakan), sedangkan kasus objektif diperankan oleh nomina kata o 'bahu'. Hal tersebut dapat terjadi bila verba struktur kalimat tersebut terjadi proses morfologis dalam bentuk pasif, sehingga makna yang terkandung menjadi pasif (oleh) dan konstituen berpemarkah datif menjadi agentif. Pada data kalimat (1), partikel $\boldsymbol{n i}$ pun dapat bermakna pelaku suatu perbuatan/benda yang menyatakan oleh. Partikel $\boldsymbol{o}$ sebagai penanda kasus objektif yang terkena efek dari suatu aktivitas atau perbuatan. Verba ini memiliki ciri makna [ + transitif]. 
Data 2:

$\begin{array}{lcc}\text { タロは } & \text { 母に } & \text { お金を } \\ \frac{\text { Taro } w a}{\text { B }} & \frac{\text { haha }}{\mathbf{A}} \boldsymbol{n i} & \begin{array}{c}\text { okane } \\ \mathbf{O}\end{array} \\ \text { Taro-Top } & \text { ibu-Dat } & \text { uang-Ak } \\ \text { もらいました。 } & \\ \text { moraimashita. } & \\ \text { menerima - lampau } & \end{array}$

'Taro menerima uang dari ibu.'

(Korpus, Gakubu: 2003)

Pada data kalimat (2) verba moraimashita 'telah menerima' memiliki kasus agentif (pelaku) haha ni 'dari ibu' pada argumen datif berpemarkah ni. Kasus benefaktif Taro wa 'Taro (nama persona) pada argumen subjek berpemarkah $w a$. Hal ini disebabkan verba morau / itadaku 'menerima' berkorelasi makna dengan pemarkah $n i$ yang bermakna asal/sumber, yaitu dari. Verba itadaku 'menerima' merupakan verba bentuk santun dalam BJ.

\section{B. Benefaktif}

Verba aksi benefaktif Bahasa Jepang mempunyai ciri semantis [aksi-benefaktif], verba aksi benefaktif adalah verba yang menyatakan tindakan dan pemilikan, mendapatkan keuntungan atau kehilangan. Pelaku verba ini adalah berupa nomina [+ bernyawa] yang bertindak sebagai pelaku tindakan. Pelaku bisa juga berperan sekaligus sebagai pemilik atau yang kehilangan. Kasus benefaktif adalah entitas yang mendapatkan atau kehilangan sesuatu.

Data 3 :

宮崎君 も友達に毎日 Miyazaki kun mo tomodachi ni mainichi A B

Miyazaki juga teman-Dat setiap hari

$\begin{array}{ll}\text { いろんな本を } & \text { 学校に } \\ \text { iron na hon }^{O} & \text { gakkou ni }\end{array}$

macam-macam buku- Ak sekolah-Lok

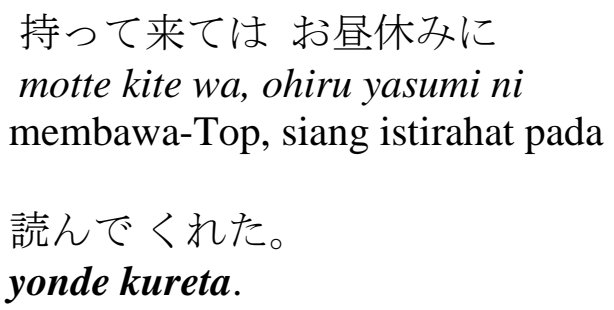

'Setiap hari Miyazaki membawa berbagai buku ke sekolah dan membacakannya untuk temanteman saat istirahat siang.'

(Korpus, Manga, 1981: 103)

Untuk data kalimat (3) nomina persona Miyazakikun mo 'Miyazaki (nama orang)' memiliki peran, yaitu sebagai kasus agentif pada argumen subjek, nomina persona tomodachi ni ' untuk teman' berperan sebagai kasus benefaktif pada argumen datif. Selain itu, makna yang terkandung pada argumen datif data kalimat (3) pun menyatakan pasien menunjukkan 'untuk' (benefaktif) .

Data 4:

$\begin{array}{ll}\text { お父さんは } & \text { 兄に } \\ \text { Otoosan } w a & \frac{\text { ani }}{\mathbf{A}} \boldsymbol{\text { B }}\end{array}$

ayah-Top kakak (laki-laki)-Dat

このうちを やずった。

kono uchio yuzuta

O

ini rumah-Ak mewariskan-lampau

'Ayah telah mewariskan rumah ini untuk kakak laki-laki.'

(Korpus,Yahoo: 2003)

Data kalimat (4) nomina persona otousan wa 'ayah' sebagai kasus agentif pada argumen subjek dan nomina persona ani ni ' untuk kakak laki-laki' pada argumen datif sebagai kasus benefaktif. Selain itu, makna yang terkandung pada argumen datif data kalimat (4) pun 
menyatakan sebagai pasien menunjukkan 'untuk' (benefaktif).

\section{Pengalam (Experiencer)}

Peran Pengalam (Experience) menyatakan makluk hidup yang mengalami pengalaman psikologis, yaitu kognisi, emosi, atau sensasi. Pada data kalimat (5) dan (6), 通らせた Itooraseta 'telah melewati',secara peran semantis sebagai Pengalam (Experiencer).

Data 5 :

先生がジロに 学校の前を

$\frac{\text { Sensei ga }}{\mathbf{A}} \quad \frac{\text { Jiro ni }}{\mathbf{E}} \frac{\text { gakkou no mae }}{\mathbf{O}}$

guru-Nom Jiro-Dat sekolah-Gen depan-Ak

通らせた。

\section{tooraseta.}

melewati-lampau

'Guru menyebabkan Jiro melewati depan sekolah.'

$$
\text { 2010) }
$$

(Korpus, Gengo.

Pada data kalimat (5), verba tooraseta 'telah menyebabkan melewati' menyatakan kasus pengalam yaitu nomina Jiro ni ' untuk Jiro (nama orang)' pada argumen datif, kasus agentif yaitu nomina sensei ga 'guru' berperan sebagai penyebab pada argumen subjek, sedangkan nomina gakkou no mae o 'melintasi depan sekolah' berperan sebagai kasus objektif sekaligus kasus lokatif. Hal itu disebabkan proses morfologis yang terjadi pada verba too $\{\boldsymbol{r u}\}$ 'melewati' + bentuk kausatif $\{\sim$ seru $\} \rightarrow$ tooraseru $+\{\sim$ ta $\} \rightarrow$ tooraseta 'telah menyebabkan melewati' dalam bentuk kala lampau menjadi pola kalimat kausatif BJ.

Data 6:

$\begin{array}{lll}\text { 母が } & \text { 子供に } & \text { 拍手を } \\ \frac{\text { Haha ga }}{\mathbf{A}} & \frac{\text { kodomo }}{\mathbf{E}=\mathbf{B}} & \frac{\text { hakushu }}{\mathbf{O}} \\ \text { ibu-Nom } & \begin{array}{l}\text { anaka-anak-Dat } \\ \text { tepuk tangan- }\end{array}\end{array}$

$\mathrm{Ak}$

している。

shite iru.

melakukan -sedang

'Ibu sedang bertepuk tangan untuk anak-anak.'

(Korpus, Yahoo: 2008)

Data kalimat (6) verba shita iru 'sedang melakukan' mengikat kasus pengalami dan benefaktif pada argumen datif yaitu kodomo ni 'untuk anak-anak'. Pada kasus objektif terdapat pada hakushu o 'tepuk tangan' dan peran agentif yaitu haha ga 'ibu' sebagai pemberi perasaan bangga kepada anak-anaknya pada argumen subjek.

\section{Objektif}

Peran objektif menyatakan entitas yang merupakan isi dari atau stimulus bagi pengalam. Kasus objektif adalah entitas yang didapatkan atau yang dihilangkan. Pada data kalimat (7) menggunakan verba 覚えた / oboeta 'telah mengingat' merupakan verba aksi objektif.

Data 7 :

$\begin{array}{cl}\text { 私が } & \text { その笑い 声に } \\ \frac{\text { Watashi ga }}{\mathbf{A = E}} & \frac{\text { sono warai goe }}{\text { O }} \boldsymbol{\text { O }} \\ \text { saya-Nom } & \text { itu tawa suara-Dat }\end{array}$

不快感を覚えた。

fukaikan $o$ oboeta.

$\mathbf{O}$

tidak nyaman-Ak ingat -lampau

'Saya (merasa) tidak nyaman mengingat suara tertawa itu.'

(Korpus, Gakubu: 2003) 
Data kalimat (7) subjek pada kalimat BJ tidak direalisasikan dalam struktur lahir kalimat, hal itu memang sering dilakukan dalam BJ. Verba oboeta 'mengingat' pada data kalimat (7) mengikat kasus agentif yang diperankan oleh nomina persona watashi ga 'saya' nomina watashi sekaligus juga berperan sebagai kasus pengalam, sedangkan kasus objektif diperankan oleh nomina sono warai goe ni '(ke)pada suara tertawa itu' pada argumen datif dan fukaikan o 'ketidaknyamanan' pada argumen objek.

Penggunaan pemarkah $\boldsymbol{n i}$ dalam kalimat pasif Bahasa Jepang adalah wajib dan makna adalah ketidaknyamanan yang dialami seseorang. Penggunaan objek ganda dengan pemarkah akusatif ' $\boldsymbol{o}$ ' Bahasa Jepang. Hal tersebut tidak berterima secara gramatikal maupun makna Bahasa Jepang. Itu disebabkan karena penggunaan objek ganda dengan istilah 'double $o$ constraint' dalam struktur kalimat BJ tidak diperbolehkan, yaitu objek ganda berpemarkah $o$ akusatif dalam satu struktur kalimat.

Struktur kalimat pasif BJ (ukemi atau judou bun) dapat dibagi menjadi dua tipe, yaitu kalimat pasif langsung (chokusetsu no ukemi) dan kalimat pasif tidak langsung (kansetsu no ukemi). Kalimat pasif langsung hanya dibentuk dari kalimat aktif transitif (nodoubun) yang objeknya berupa manusia atau binatang, secara langsung dikenai perbuatan. Nomina jenis inanimate tidak bisa dijadikan subjek dalam kalimat pasif BJ. Kalimat pasif tidak langsung dapat dibentuk dari verba transitif maupun dari verba intransitif. Kalimat pasif tidak langsung BJ, yang dikenai perbuatan secara langsungnya adalah bukanlah subjek. Oleh karena itu, hal tersebut dalam Bahasa Jepang disebut dengan meiwaku no ukemi. Pada struktur kalimat pasif di atas, bahwa kalimat pasif BJ wajib menggunaan pemarkah datif $\boldsymbol{n i}$ dan verba bentuk pasif BJ. Hal itu diasumsikan dapat terjadi karena verba bentuk pasif BJ, memunculkan makna inhern verba itu sendiri yang menunjukkan ketidaknyamanan, kesedihan atau mengganggu perasaan.

Pemarkah $\boldsymbol{n i}$ yang dipergunakan dalam struktur pasif BJ menyatakan argumen datif, bermakna pelaku (oleh), namun bukanlah argumen datif sebagai objek taklangsung BJ. Oleh karena itu, bila verba tersebut diubah ke dalam bentuk kalimat aktif, makna gramatikal kalimat tersebut menjadi berbeda. Jikalau pemarkah ni dalam struktur kalimat pasif BJ disubstitusi dengan pemarkah akusatif $\boldsymbol{o}$ atau nominatif $\boldsymbol{g} \boldsymbol{a}$, maka akan mengubah makna dan menjadi tidak berterima dalam Bahasa Jepang. Sehingga dalam padanan dalam bahasa Indonesia pun harus disesuaikan artinya dengan konteks kalimat yang ada.

Pola kalimat kausatif [ $\sim \boldsymbol{n i}$ kausatif] BJ tersebutlah yang menyebabkan memunculkan konstituen datif yang menyatakan causee's 'sesuatu yang menjadi sebab' dalam struktur kalimat itu. Struktur kalimat kausatif Bahasa Jepang [ $\boldsymbol{n i}$ kausatif] merupakan struktur kalimat kausatif bermakna menyuruh, membuat menyebabkan seseorang melakukan sesuatu melalui proses morfologis pada verbanya.

Sebagai contoh verba menyatakan struktur kalimat BJ dari verba $\boldsymbol{y o}\{\boldsymbol{m u}\}+\{\sim$ seru $\}$ (kausatif) $+\rightarrow\{\sim$ ta $\}$ menunjukkan kala lampau yang merupakan verba transitif berpemarkah $\boldsymbol{o}$ [ $\boldsymbol{o}$ kausatif].

Data 8:

$\begin{array}{lll}\text { 友達は } & \text { 私に } & \text { 漫画を } \\ \text { Tomodachi wa } & \text { watashi ni } & \text { manga o } \\ \text { teman-Top } & \text { saya-Dat } & \text { komik-Ak }\end{array}$

\section{読まれた。 \\ yomaseta.}

membaca (menyebabkan)-lamp

'Teman telah (membuat/menyebabkan) saya membaca komik.'

(Furanki: 2005 : 57)

Data 8a :

$\begin{array}{lll}\text { 友達は } & \text { 漫画を } & \text { 読ませた。 } \\ \text { Tomodachi wa } & \text { manga o } & \text { yomaseta } \\ \text { teman-Top } & \text { komik-Ak } & \text { membaca- } \\ \text { (menyebabkan)-lampau } & \end{array}$


'Teman membaca komik.'

Data 8b :

*友達は 私を漫画を

Tomodachi wa watashio manga o teman-Top saya-Ak komik-Ak

読まれた。

yomaseta.

membaca (menyebabkan)-lamp

*'Teman telah (membuat/menyebabkan) membaca saya komik.'

Data 8c :

*友達は 私に 漫画に

Tomodachi wa watashi ni manga ni teman-Top saya-Dat komik-Dat

読まれた。

yomaseta.

membaca (menyebabkan)-lamp

* 'Teman telah (membuat/menyebabkan) saya membaca untuk komik.'

Namun, dengan pola kalimat kausatif BJ pada data kalimat (8b), menggunakan pemarkah o pada argumen objek langsung, begitu pula pemarkah $\boldsymbol{o}$ pada argumen datif dalam satu struktur kalimat kausatif. Penggunaan pemarkah o ganda dalam suatu struktur kalimat akan menjadi tidak berterima secara gramatikal makna dalam struktur kalimat BJ. Hal ini disebut sebagai 'the double o contraint' atau objek $\boldsymbol{o}$ ganda. Penggunaan objek $\boldsymbol{o}$ ganda pada [okausatif] itu merupakan pencegahan klausa dari memiliki dua NP (noun phrase) yang ditandai dengan partikel kasus akusatif. Jadi, secara gramatikal dalam kalimat kausatif (8b) di atas, dengan menandai NP (noun phrase) cause 'sebab' yang sesuai dengan pemarkah ni dalam membentuk [ $\sim \boldsymbol{n i}$ kausatif], dan NP (noun phrase) kedua ditandai dengan pemarkah $\boldsymbol{o}$ yang menyatakan objek langsung. Argumen causer 'penyebab' yang dihasilkan berarti bahwa subjek menyebabkan causee 'sesuatu yang menjadi sebab' untuk melakukan tindakan yang disebutkan dengan verba.

Karena penggunaan verba yоти 'membaca' seperti data kalimat (8c) merupakan katai rengo (pembentukan nomina yang bersifat ketat), sehingga pemarkah yang dipergunakan pun wajib yaitu pemarkah akusatif $\boldsymbol{o}$ yang berasosiasi makna menyeberangi atau melewati suatu ruang yang menyatakan objek langsung.

Aturan dasar pada bahasa Jepang (BJ) bahwa verba intransitif tidak memunculkan pemarkah objek, kecuali verba intransitif yang menunjukkan perpindahan baik ruang maupun waktu. Verba aruku 'berjalan' dan wataru 'menyeberang' yang merupakan verba intransitif, sehingga tidak membutuhkan objek, namun membutuhkan nomina yang membatasinya sebagai pelengkap. Hal tersebut, yang menyebabkan terjadinya penambahan argumen datif, selain karena terjadinya proses morfologis pada struktur kalimat Bahasa Jepang tersebut. Nomina tersebut merupakan pelengkap wajib yang sifatnya selaras dengan objek dalam konstruksi NP + Po (Post posisi) $+\mathrm{V}$, sehingga pemarkah yang dimilikinya pun sama dengan pemarkah objek. Hubungan objektif maupun kondisional dalam konstruksi $\mathrm{NP}+\mathrm{Po}+\mathrm{V}$ ditentukan oleh verba yang menjadi intinya. Verba transitif menentukan hubungan objektif, sedangkan verba intransitif menentukan hubungan kondisional. Namun, tiap verba (transitif atau intransitif) masing-masing memiliki makna tertentu yang terkandung di dalamnya, sehingga hubungan yang terbentuk menjadi sangat bervariasi.

Verba transitif seperti ageru 'memberi', morau 'menerima', kariru 'meminjam', dan lainnya menunjukkan hubungan objektif kepemilikan 'shoyuu' 所有, sehingga nomina yang dapat bergabung dengannya merupakan objek berupa benda atau barang yang dapat dimiliki. Demikian pula, pada verba intransitif seperti iku 'pergi', kuru 'datang', wataru 'menyeberang', dan modoru 'kembali', yang 
menyatakan verba bergerak 'idou doushi' 移動動 詞 menunjukkan hubungan kondisional perpindahan ruang 'kuukantekina musubitsuki' 空 間的なむすびつき, sehingga nomina yang bergabung dengannya merupakan nomina berjenis tempat atau lokasi.

\section{KESIMPULAN \& SARAN}

Peran semantis yang bertindak pada argumen datif atau objek tidak langsung dalam struktur BJ adalah (1) Agentif , (2) Benefaktif, (3) Pengalam (experiencer), dan (4) Objektif. Lebih spesifik lagi, yang dinyatakan oleh peran semantis pada argumen datif dalam penelitian ini adalah : (1) agentif yang bermakna sumber atau asal, (2) benefaktif makna yang terkandung dapat menyatakan (a) untuk, (b) sasaran yang menyatakan kepada, (3) Pengalam yang bermakna kognisi, dan (4) Objektif bermakna objek dari verba. Kaitan penggunaan verba dan peran semantis yang muncul pada argumen datif atau objek tidak langsung adalah:

Ciri-Ciri Kasus Verba Aksi Berkonstituen Datif

\begin{tabular}{|l|l|l|l|l|}
\hline $\begin{array}{l}\text { Verba } \\
\text { Aksi }\end{array}$ & A-O & A-E-O & A-B-O & B-A-O \\
\hline
\end{tabular}

Verba pada peran semantis agentif merupakan verba transitif/ aksi yang dapat berupa bentuk pasif [ reru/ rareru] bahasa Jepang. Dan verba pada peran semantis pengalam dapat berupa verba intransitif yang berpola kausatif [ seru] bahasa Jepang yang menyatakan verba bergerak 'idoudoushi'.

\section{DAFTAR PUSTAKA}

Aryani, MRD. 2017. "Datif dalam Bahasa Jepang. Kajian Sintaktis dan Semantis" (disertasi). Bandung: Universitas Padjadjaran

Bache, Carl. 1995. The Study of Aspect, Tense, and Action. Frankfurt am Main: Peter Lang.
Blake, Barry J.2001. Case. Cambridge: Cambrige University Press

Bresnan, J. 2001. Lexical Functional Syntax. Oxford: Blackwell Publishers.

Budiarta, I Wayan. 2012. 'Aliansi Gramatikal Bahasa Dawan: Kajian Tipologi Bahasa'. V. 19, Maret 2012 ISSN: 0854-9613 Linguistika: Buletin Ilmiah Program Magister Universitas Udayana

Butt, Miriam. 2006. Theory of Case. Cambridge: Cambridge University Press

Cook, Walker A. 1979. Case Grammer: Development of the Matrix Model Washington, DC: Georgetown University Press.

Diah, Wahyuning. 2018. 'Faktor-faktor yang Mempengaruhi Pemilihan Ungkapan Perintah Bahasa Jepang dalam Teks Percakapan : Kajian Kesantunan Berbahasa'. V.25, no. 48, p. 35-46, Maret 2018 ISSN: 0854-9613 Linguistika: Buletin Ilmiah Program Magister Universitas Udayana.

Givon, Talmy. 2001. Syntax An Introduction. Vol II. Amsterdam: John Benjamins Publishing Company.

Nitta, Yoshio. 1991. Nihongo Bunpou Kenkyuu Josetsu. Toukyou-Japan: Kuroshio Shuppan

Shibatani, Masayoshi. 2012. Grammatical Relations and Surface Cases. USA: Linguistic Society of America http://www.jstor.org/page/info/about/polic ies/terms.jsp

Sugai, Kazumi. 2000. 'Kakujoshi ni no Imi Tokusetsu ni Kansuru Oboegaki' dalam Hyougo Kyouikudaigaku Kenkyuu Kiyou Vol. 20

Verhaar, JWM. 1999. Asas- Asas Linguistik Umum. Yogyakarta: Gadjah Mada University 